\title{
Some Thoughts on a History of the Business Man
}

The publication of an 800 -page volume on the business man from ancient times to the New Deal is an event of considerable importance to those interested in the history of business. A comprehensive survey of the historical experience and development of business has long been needed. Such a volume would have a double meaning: it could both point out what is known of business in the past and, by the character of what it contains and does not contain, indicate where further study should be made.

Miriam Beard's A History of the Business Man is a very ambitious work, one that has required a prodigious amount of searching into the history of many countries. No doubt it gives much that would be of great interest to business men. It is not the object of this comment, however, to evaluate the book but rather to point out some reflections which it has called forth.

In her introduction, Miss Beard very effectively considers the barrenness of the history of business. Why have Church and State and the Arts been given so much attention by historians, while business has had little more than a passing glance? Is it that the business man has not burned heretics or killed enough of his enemies? Is it that he has not stood for any great principle or purpose? Or is it that business men have themselves not had any realization of their significance and have, therefore, neither written of their experiences nor encouraged others to do so? Can it even be said that business men have had something to hide? Miss Beard holds that this comparative silence on the part of the historians is the result in considerable measure of the fact that the most articulate groups, historically, have been those who, like the feudal aristocracy, have been opposed to business or have looked down on the business man.

Whatever the reason, the fact remains that the history of business is a relatively unexplored field. It is true that a great deal is known about the business man of the past, as Miss Beard's book reveals, much that is both interesting and significant. It is important to know that business men have helped to make and to break emperors, that they have dictated the policies of governments, and that they have furthered culture by the patronage or employ- 
ment of artists; all this helps to explain great political and social movements and developments, and brings historical knowledge closer to that reality which it must have to be of value. Moreover, it is well to make known that business men have not infrequently acted the part of the parvenu and that, in their drive toward profits they have often been exploiters rather than producers of goods or services; such knowledge should help to arouse that self-criticism which is necessary not only to effective operation but also to survival in a dynamic society. But that is not the whole or perhaps even the most important part of the history of the business man.

After all is said and done, the most important thing the business man has done has been to carry on business, to produce goods and services and to make them available when and where required, that is, to act as the organizer and administrator of economic effort. One might hold that the really significant contribution of the present volume is that it so clearly reveals the need of further historical study of the work of the business man. Not that Miss Beard fails altogether to deal with his work; occasionally, and particularly for medieval times, she treats business with some insight. But the business man at work, what he tries to do, what he accomplishes, the institutions through which he works, the techniques he employs, the problems he faces-in general, business policy and administration and the flow of efforts and results-are outside the main interest of the book. This point would not be worth noting if it were meant merely to call attention to any shortcoming in the book in question. To the commentator the fact is significant because it so strikingly illustrates the lack of satisfactory material on the history of business. Miss Beard is not the muckraker or the cheap popularizer; granted that she suffers from the professional scholar's lack of experience with business and looks at business chiefly from the point of view of the cultural historian, still she has a considerable appreciation of the realities of the subject. Sometimes, it is true, she has failed to make use of recent books which would have been very helpful, but by and large her work is drawn from recognized authorities. The conclusion is that the history of business is still almost an unknown field.

This situation need not be so. Few business men have left conscious expression of their work-like most men of action they have been inarticulate, and from design or otherwise few have employed others to record their work in business-but there exists a wealth of records of business operations, from medieval times to the present, records in the form of business account books and correspondence, 
business manuals, government documents, and other contemporary materials. When the constitution and administration of business have been studied from such records, as the constitution and administration of governments have been studied by political historians, we shall have a clearer conception of the development of our business system. It is interesting to speculate on what Miss Beard's book would have been like if she had written from a wealth of historical studies drawn from such sources.

Henrietta M. Larson

\section{The Brighton Market Bank}

The Business Historical Society has recently received from the First National Bank of Boston several volumes of records of the Brighton Market Bank, later the National Market Bank of Brighton. The gift includes several books recording names of stockholders and transfers of stock, a book giving the minutes of stockholders' meetings, and a volume of directors' minutes. The directors' minute book begins with 1854 and ends in 1891 .

The directors' minute book tells a very important story. It is to be regretted that the set of books includes no ledgers, for without them no detailed, and hence satisfactory, study can be made of the Brighton Bank. But something of the history of the Bank that is important can be gained from the minute book. Some statistics gleaned from the volume and a few facts chosen here and there on the history of this early Brighton bank will illustrate the nature of the material contained in the directors' records.

First, just a few words about the Bank and the conditions under which it was to work. The Brighton Bank was clearly organized to serve the livestock market in Brighton, now a part of Boston. Brighton was then the stockyard and packing center of the Boston area; it was the training school of Gustavus Swift, who founded the great Chicago meat-packing firm which bears his name. The Bank was established in the 1850's when there was no national regulation of banking and no national system of banking or national bank currency. The years covered by this volume brought great developments and great problems in American business: the Brighton Market Bank was floated in the boom following the depression of 1854 and preceding the panic of 1857, and the decades which followed, down to 1891, brought war, expansion, and long periods of depression, while the meat-packing industry experienced a shift 